\title{
ZARYS PROBLEMATYKI BUDOWNICTWA I STRAT WOJENNYCH W KOŚCIOLACH PARAFIALNYCH DIECEZJI LUBELSKIEJ PO I WOJNIE ŚWIATOWEJ
}

Kwestia budowy i odbudowy kościołów i budynków parafialnych stała się po I wojnie światowej jedną z kluczowych zarówno dla struktur kościelnych, jak i dla niepodległego państwa polskiego. Prace nad ujednoliceniem oraz zmodernizowaniem prawa budowlanego w Polsce trwały blisko dziesięć lat. Do tego czasu na ziemiach byłego zaboru rosyjskiego, obowiązywały normy prawne z 1917 r., wydane przez niemieckiego generał-gubernatora, jak również przestarzałe dziewiętnastowieczne przepisy budowlane. Część z nich stopniowo uchylano ${ }^{1}$. Sformułowanie całkowicie nowych, dostosowanych do nowej sytuacji politycznej przepisów w zakresie budownictwa wymagało wielu kompromisów i konfrontacji, pogodzenia interesów i oczekiwań hierarchów z tym co miały do zaproponowania władze państwowe. Wypracowywanie wspólnych, godzących interesy obu stron, rozwiązań dokonywało się etapami, kończącymi się nowymi regulacjami prawnymi, ogłaszanymi w postaci ustaw i rozporządzeń. Mając na uwadze wielkość szkód materialnych, jakie wyrządziła I wojna światowa, w pierwszej kolejności sformułowano przepisy dotyczące odbudowy zniszczeń powojennych, jakim uległy między innymi kościoły i budynki parafialne. Pierwszym aktem prawnym w tej sprawie była Ustawa sejmowa z dnia 28 lutego $1919 \mathrm{r}$. w sprawie zaopatrzenia ludności $w$ drzewo budulcowe i opałowe $e^{2}$. Obowiązywała ona do dnia 25 lutego 1932 r., kiedy to została uchylona ${ }^{3}$. Według późniejszego rozporządzenia do tejże ustawy wydanego 3 lutego 1920 r., pierwszeństwo w przydziale drewna budulcowego w celu odbudowy zniszczonych budynków miało przysługiwać gospodarstwom drobnym, szkołom, kościołom i budynkom użyteczności publicz-

* Joanna Kumor-Mielnik - dr historii, adiunkt w Ośrodku Geografii Historycznej Kościoła w Polsce, e-mail: kumorj@kul.lublin.pl

${ }^{1}$ Cz. Krawczak, Prawo budowlane na ziemiach polskich od połowy XVIII wieku do 1939 roku, Poznań 1975, s. 118; J. Żywicki, Architektura neogotycka na Lubelszczyźnie, Lublin 1998, s. 31.

${ }^{2}$ Dziennik Praw 1919, Poz. 229, Nr 20, s. 374; Krawczak, Prawo budowlane, s. 117.

${ }^{3}$ Dziennik Ustaw 1932, Poz. 232, Nr 26, s. 416. 
nej . Wysokość i rodzaj pomocy finansowej państwa na cele odbudowy tychże budynków została określona na mocy Ustawy z dnia 18 lipca 1919 r. o pomocy państwowej na odbudowe gospodarstw, zniszczonych lub uszkodzonych skutkiem wojny. Artykuł 4. niniejszej ustawy stanowił, iż pomocą państwową w zakresie odbudowy zniszczonych budynków objęte zostaną również kościoły, a ponadto, między innymi kościołom pomoc ta będzie udzielana w pierwszej kolejności. Kolejne artykuły określały formę i wysokość pomocy finansowej, która miała być udzielana częściowo $\mathrm{w}$ postaci bezzwrotnej zapomogi pieniężnej do wysokości 20000 marek (w przypadku nieruchomości domowych do dwóch tysięcy marek), a częściowo w formie pożyczki bezprocentowej, przez pierwszych pięć lat (artykuły: 7, 8, 9, 10)5. Dnia 15 lipca 1920 r. ogłoszona została kolejna ustawa, która rozszerzyła tekst artykułu 8. ustawy z 18 lipca 1919 r. W nowym zapisie tegoż artykułu wysokość zapomogi pieniężnej określona została w procentach i w rezultacie miała ona wynosić $50 \%$ oszacowanych strat wojennych, a do czasu przeszacowania i ustalenia kursu waluty, zapomoga miała wynosić 50\% rzeczywistych kosztów odbudowy ${ }^{6}$. Ustawy te uchyliła kolejna wydana 6 maja 1924 r. o pomocy państwowej na odbudowę budynków zniszczonych lub uszkodzonych wskutek działań wojennych. Zgodnie z artykułem 4. i 5. tejże ustawy, starający się o pożyczkę winien do podania dołączyć kosztorys, względnie wykaz szkód oszacowany w złotych bądź w markach polskich, przy czym marki polskie miały być przeliczane na złote według stosunku, który zostanie ustalony w rozporządzeniu Ministra Robót Publicznych, wydanym w porozumieniu z Ministrem Skarbu. Ponadto w artykule 8. niniejszej ustawy zapisano, że po wykonaniu prac związanych z odbudową pożyczka może zostać w części lub w całości umorzona ${ }^{7}$. Nieznaczne zmiany w zakresie zasad umarzania pożyczek budowlanych wprowadziły dwa kolejne akty prawne: pierwszy z 18 lutego $1932 \mathrm{r}^{8}{ }^{8}$ oraz drugi z 18 marca 1933 r. ${ }^{9}$

Sprawa pomocy państwa w odbudowie zniszczonych świątyń i budynków kościelnych została mocno zaakcentowana przez bpa Adolfa Szelążka już na w początkach 1919 r., jak również podczas dyskusji nad projektem konkordatu z 1925 r. Bp Szelążek będąc szefem Wydziału Wyznania Katolickiego w Departamencie Wyznań Religijnych, w piśmie z 1919 r. zwrócił się do Ministra Wyznań Religijnych i Oświecenia Publicznego [MWRiOP] z prośbą o wsparcie finansowe dla zrujnowanych świątyń katolickich położonych w diecezjach byłego Królestwa Polskiego. Zwracał uwagę na skalę zniszczeń, pisząc: „Pożoga wojenna zostawiła swe ślady przede wszystkim na świątyniach katolickich. Strony wojujące niszczyły te budowle pod pozorem usuwania oparcia dla przeciwnika w działaniach wojennych. Szczególnie wojska moskiewskie względami militarnymi pokrywały barbarzyńską w rzeczy samej chęć burzenia tych filarów życia narodo-

\footnotetext{
${ }^{4}$ Dziennik Ustaw 1920, Poz. 76, Nr 14, s. 171; Krawczak, Prawo budowlane, s. 117.

${ }^{5}$ Dziennik Praw 1919, Poz. 368, Nr 63, s. 650-652.

${ }^{6}$ Dziennik Ustaw 1920, Poz. 405, Nr 62.

${ }^{7}$ Dziennik Ustaw 1924, Poz. 492, Nr 49, s. 724-726.

${ }^{8}$ Dziennik Ustaw 1932, Poz. 131, Nr 19, s. 299.

${ }^{9}$ Dziennik Ustaw 1933, Poz. 206, Nr 25, s. 549-550.
} 
wego. Cofające się z Polski armie rosyjskie rujnowały kościoły katolickie... Zebrane przez Departament Wyznań wykazy szkód wojennych w zakresie budynków kościelnych przedstawiają sumę przeszło sześciu i pół miliona rubli. Znaczną część tej sumy stanowią świątynie... Ludność katolicka znajduje się z tego powodu w niezmiernie trudnym położeniu co do zaspokajania swoich potrzeb religijnych. Na znacznych obszarach Polski wojna obróciła w perzynę liczne siedziby ludzkie. [...] Wierni jednak, dla których obowiązki religijne w szeregu zadań duchowych stoją na miejscu naczelnym, zwracają się do władz diecezjalnych z usilnymi prośbami o wyszukanie środków pomocy w tej sprawie. Oczywiście, w obecnych warunkach niepodobna myśleć o stosowaniu określonego przez prawo rozkładu na parafian kosztów odbudowy zrujnowanych świątyń. [...] Potrzebę szybkiej odbudowy świątyń wywołują także względy kultury narodowej. Niektóre spośród zburzonych lub bardzo uszkodzonych świątyń stanowiły dorobek cywilizacyjny naszej przeszłości; były to wybitne dzieła sztuki plastycznej, - pomniki architektoniczne pierwszorzędnego znaczenia. [...] Trzeba uwzględnić również tę okoliczność, że poważna część zrujnowanych podczas wojny świątyń zawdzięcza istnienie swoje ofiarności ludu wiejskiego. W wieku dziewiętnastym sam lud prawie wyłącznie budował nasze kościoły. [...]. Odbudowa świątyń katolickich przedstawia obszerne pole pracy. [..." ${ }^{\prime 10}$.

Spośród wszystkich diecezji znajdujących się w granicach byłego Królestwa Polskiego, największe straty w kościołach, poniosła obok archidiecezji warszawskiej, diecezja lubelska (wraz z przyłączoną do niej w 1867 r. diecezją janowską czyli podlaską, reaktywowaną w 1918 r.), w dalszej kolejności diecezja sandomierska, płocka, kielecka, sejneńska oraz kujawsko-kaliska.

Straty w kościołach poniesione przez poszczególne diecezje byłego Królestwa Polskiego, oszacowane w 1918 r. i wykazane w rublach, przedstawia tabela 1.

Tabela 1. Powojenne straty w kościołach, według diecezji byłego Królestwa Polskiego, oszacowane w rublach w 1918 r./

Table 1. Postwar losses in churches in the dioceses of the former Kingdom of Poland, estimated in rubles in 1918.

\begin{tabular}{|l|r|}
\hline Diecezja augustowska czyli sejneńska & 562.730 \\
\hline Diecezja kielecka & 625.043 \\
\hline Diecezja kujawsko-kaliska & 135.160 \\
\hline Diecezja lubelska & 1.076 .116 \\
\hline Diecezja płocka & 860.780 \\
\hline Diecezja sandomierska & 1.004 .620 \\
\hline Archidiecezja warszawska & 1.085 .734 \\
\hline Ogólna suma strat w rublach & 5.350 .183 \\
\hline Ogólna suma strat po przeliczeniu rubli na marki & 50.289 .345 \\
\hline
\end{tabular}

Źródło: Archiwum Akt Nowych w Warszawie, Ministerstwo Wyznań Religijnych i Oświecenia Publicznego, sygn. 692, nr mikrofilmu B 9686, k. 21.

${ }^{10}$ Archiwum Akt Nowych w Warszawie (dalej: AAN), Ministerstwo Wyznań Religijnych i Oświecenia Publicznego, sygn. 692, k. 15-18, nr mikrofilmu B 9686 
Wysokość dotacji państwowych na odbudowę zniszczonych świątyń i budynków kościelnych określona została w Aneksie A do artykułu XXIV konkordatu z 10 lutego 1925 r. Spośród wymienionych w Aneksie A świadczeń państwa na rzecz Kościoła, znalazł się również roczny fundusz budowlany, na który państwo zobowiązało się przeznaczać ponad jeden milion złotych. Kwota ta, w przypadku dewaluacji złotego miała być przeliczana według ówczesnej wartości pieniądza, aby Kościół nie był narażony na straty. Dotacje z funduszu budowlanego miały być przyznawane poszczególnym diecezjom ${ }^{11}$. Jak wynika z ustaw i rozporząazeń państwowych, wydanych w pierwszym dziesięcioleciu po odzyskaniu przez Polskę niepodległości, wszelkie działania podejmowane zarówno przez państwo, jak i Kościół w sferze budownictwa sakralnego, ukierunkowane były przede wszystkim na odbudowę zniszczonych świątyń i innych budynków kościelnych. Dlatego też liczba nowo wybudowanych świątyń w diecezji lubelskiej w okresie międzywojennym nie była imponująca. W latach 1918-1930 wybudowano w diecezji lubelskiej 16 kościołów parafialnych w miejscowościach: Abramów, Chmiel, Dzwola, Gościeradów, Klementowice, Kłodnica, Kraczewice, Krynice, Leszkowice, Orłów Murowany, Podhorce, Puszcza Solska (obecnie Biłgoraj), Suchowola Radzyńska, Trzeszczany, Wierzchowiska, Wola Gałęzowska i jeden filialny w Białej Ordynackiej. Budowy czterech spośród 16 świątyń zainicjowane zostały jeszcze przed wybuchem I wojny światowej. Były to kościoły w Gościeradowie, Klementowicach, Orłowie Murowanym oraz w Trzeszczanach. Aż w przypadku połowy kościołów parafialnych wzniesionych w latach 1918-1930, materiałem budowlanym było drewno. Drewniane kościoły powstały w Abramowie, Białej Ordynackiej, Kłodnicy, Kraczewicach, Krynicach, Leszkowicach, Wierzchowiskach oraz Woli Gałęzowskiej; pozostałe kościoły były murowane. Pod koniec lat dwudziestych zapoczątkowano budowę kościołów: w Lublinie pw. św. Michała Archanioła, w Gilowie, Polichnie, Starościnie i Zagłobie ${ }^{12}$. Prace budowlane ukończono w następnym dziesięcioleciu. Stosunkowo duża liczba nowo wybudowanych w tym okresie kościołów drewnianych nie jest zaskakująca, bowiem wobec powojennej drożyzny materiałów budowlanych wykorzystywano w budownictwie sakralnym najtańszy budulec, jakim było drewno. Ponadto przepisy prawa budowlanego nie były aż tak bardzo restrykcyjne w stosunku do budynków wznoszonych z materiałów łatwopalnych.

${ }^{11}$ S. Łukomski, Konkordat zawarty dnia 10 lutego 1925 roku pomiędzy Stolica Apostolska i Rzeczapospolita Polska, Łomża 1934, s. 234-239; J. Wisłocki, Konkordat polski z 1925 roku. Zagadnienia prawno-polityczne, Poznań 1977, s. 99.

${ }^{12}$ Informacje o kościołach zebrane i usystematyzowane w oparciu o następujące schematyzmy (archi)diecezji lubelskiej: Catalogus Ecclesiarum et Utriusque Cleri tam Saecularis quam Regularis Dioecesis Lublinensis et Janoviensis seu Podlachiensis pro Anno Domini 1918; Catalogus Ecclesiarum et Utriusque Cleri tam Saecularis quam Regularis Dioecesis Lublinensis pro Anno Domini 1919; Catalogus Omnium Ecclesiarum et Universi Cleri Dioecesis Lublinensis pro Anno Domini 1920; Catalogus Ecclesiarum et Cleri Dioecesis Lublinensis pro Anno Domini [1921-1929]; Katalog Kościołów i Duchowieństwa Diecezji Lubelskiej na rok [1930-1934]; Spis Kościołów i Duchowieństwa Diecezji Lubelskiej [1935-1966]; Diecezja Lubelska. Informator historyczny i administracyjny, oprac. M.T. Zahajkiewicz, Lublin 1985; Archidiecezja lubelska. Historia i administracja, red. M.T. Zahajkiewicz, Lublin 2000. 
Jak już pisaliśmy, od roku 1918 budownictwo sakralne podlegało zarówno przepisom prawa państwowego, jak i rozporządzeniom wewnętrznym zawartym w Kodeksie Prawa Kanonicznego z 1917 r. Zgodnie z nim wydanie zezwolenia na budowę nowej świątyni znajdowało się w kompetencji władzy duchownej. Ponadto $\mathrm{w}$ kwestii budownictwa drewnianego sformułowano przepis zakazujący konsekrowania obiektów drewnianych, zezwalając jedynie na ich poświęcenie, w ten sposób nadając kościołom drewnianym charakter tymczasowy. Oczekiwano, że kościoły drewniane zostaną z upływem czasu zastąpione świątyniami trwałymi - murowanymi ${ }^{13}$. W miejscowościach gdzie kościoły drewniane zastępowano z czasem nowymi - murowanymi, dotychczasową drewnianą świątynię przekazywano lub sprzedawano do parafii niemającej własnego domu modlitwy. Tak stało się w przypadku drewnianego kościoła parafialnego w Siedliszczu, który w 1920 r. został zakupiony do Kawęczyna, natomiast parafii w Siedliszczu przekazano murowaną cerkiew poprawosławną, rekoncyliowaną na świątynię rzymskokatolicką. Przeniesieniu uległ także drewniany kościół w Pawłowie, który po wzniesieniu tam nowego murowanego, został translokowany w 1912 r. do parafii pw. Michała Archanioła w Lublinie, gdzie funkcjonował do czasu wybudowania murowanego kościoła, który wzniesiono w latach 1927-1938. W dalszej kolejności drewniany kościół z Pawłowa został przeniesiony do parafii w Kazimierzówce, służąc wiernym do początku lat 90 . XX w., kiedy to zastąpiono go nową murowaną świątynią. Nieco krótszą drogę przemierzyły drewniane kościoły z Dorohuska oraz z Zemborzyc. Pierwszy z nich w 1922 r. zakupiła parafia Ruda Huta, użytkując go do czasu wzniesienia w latach 1953-1960 własnego murowanego kościoła. Z kolei świątynia parafialna z Zemborzyc, gdzie w latach 1906-1907 wymurowano nowy kościół, przeniesiona została w 1918 r. do Motycza, funkcjonując w tamtejszej parafii do roku 1994, kiedy to uległa spaleniu. Na jej miejsce w latach 1994-1996 wzniesiono nowy, murowany kościół. Z kolei do czasu wybudowania kościoła parafialnego w Godziszowie, co nastąpiło w latach 1934-1937, funkcję kościoła parafialnego pełniła tam drewniana kaplica, zakupiona w $1928 \mathrm{r}$. w Dzwoli. Również parafia Księżomierz, do chwili wzniesienia w latach 19961998, nowego murowanego kościoła, użytkowała drewniany kościółek przeniesiony w 1783 r. z Chodla. Częściowo także i parafia Krynice przejęła kościół z Horyszowa Polskiego, gdzie w związku z rewindykacją murowanej cerkwi, wzniesiony przez mieszkańców Horyszowa w latach 1918-1920 (lecz jeszcze nie ukończony) drewniany kościółek, został w 1920 r. przeniesiony do Krynic.

W sprawie kościołów zabytkowych, wspomniany już konkordat z 1925 r., w artykule XIV nakazywał utworzenie w każdej diecezji komisji artystyczno-budowlanych, składających się z przedstawicieli administracji państwowej i kościelnej, a ponadto podkreślał, że: „Żadna budowa, przemiana lub restauracja kościołów i kaplic nie będzie dokonywana inaczej, jak tylko zgodnie z technicznemi i artystycznemi przepisami ustaw, dotyczących budowy gmachów i konserwacji zabytków"14.

${ }^{13}$ G. Ruszczyk, Drewniane kościoły w Polsce 1918-1939. Tradycja i nowoczesność, Warszawa 2001, s. 104.

${ }^{14}$ Konkordaty pomiędzy Stolica Apostolska a Polska z 1925 i 1993 roku. Katalog dokumentów, oprac. J. Staszków, Kraków 2006, s. 18; „Wiadomości Diecezjalne Lubelskie”, 7(1925) Nr 6, s. 
Charakteryzując ruch budowy kościołów parafialnych w latach 1918-1930, możemy powiedzieć, że w stosunku do pierwszego dziesięciolecia XX w. był on znacznie mniej dynamiczny. Przyczyną takiego stanu należy szukać w rewindykacjach cerkwi pounickich i poprawosławnych rekoncyliowanych na kościoły rzymskokatolickie oraz w ukierunkowaniu wszelkich działań na odbudowę zniszczeń powojennnych. W pierwszym przypadku, przejmowanie cerkwi przez łacinników, uzupełniało niedobór kościołów parafialnych we wschodnich i południowo-wschodnich dekanatach diecezji lubelskiej. W drugim zaś przypadku, bilans strat powojennych wymagał skoncentrowania sił i nakładów finansowych głównie na pracach związanych $\mathrm{z}$ odbudową i remontami zarówno kościołów, jak i budynków przykościelnych. Według wykazu wszelkiego rodzaju zniszczeń i uszkodzeń, których świątynie doznały podczas I wojny światowej, ponad połowa $\mathrm{z}$ nich wymagał prac remontowych, zaś 8 świątyń, w tym 4 drewniane i 4 murowane zostało spalonych. Wśród nich znalazły się: drewniany kościół w Białej przynależnej do parafii Janów Lubelski, także drewniany kościół w Chodywańcach. Spalona została też drewniana świątynia w Sitańcu, zaś wzniesiony tam w latach 1907-1913 kościół murowany został uszkodzony. Ten sam los spotkał dwa kościoły w Garbowie, z których jeden drewniany został strawiony przez pożar, zaś murowany z lat 1907-1911 został uszkodzony. Z kolei w Fajsławicach spłonął murowany kościół parafialny, odbudowany w okresie powojennym. Również po wojnie przystąpiono do odbudowy zniszczonego przez pożar murowanego kościoła w Rybitwach, z którego ocalały uszkodzone pociskami ściany. W przynależnym do parafii Rybitwy Józefowie nad Wisłą spaleniu uległ murowany kościół, zaś w Niedrzwicy Kościelnej murowany kościół parafialny najpierw został zbombardowany, a następnie spłonął. Zniszczona została także tamtejsza dzwonnica oraz parkan przykościelny.

W powojennym wykazie strat i zniszczeń uwzględniona została liczba dzwonów zarekwirowanych głównie przez wojska rosyjskie. Na 162 kościoły zamieszczone w tymże wykazie, dla 144 posiadamy informację o dzwonach. Wśród 144 kościołów, aż 136 utraciło dzwony, bądź to na skutek ich rekwizycji, bądź też z powodu pożaru kościoła w którym spłonęły. W 17 kościołach dzwonów nie skonfiskowano, zaś w parafii Boiska dzwony zostały wcześniej schowane, co zapobiegło ich grabieży. Liczba utraconych w latach 1914-1915 przez poszczególne parafie i kościoły dzwonów wyniosła 394 i 11 sygnaturek. W przypadku 4 parafii mamy tylko informację o rekwizycji dzwonów, natomiast nie mamy podanej ich liczby. Prawdopodobnie w latach 1914 i 1915 kościoły diecezji lubelskiej utraciły około 400 dzwonów i 11 sygnaturek. Dla porównania archidiecezja warszawska w okresie II wojny światowej utraciła około 115 dzwonów ${ }^{15}$. Zamieszczona poniżej tabela nr 2 zawiera wykaz kościołów wraz z liczbą utraconych przez nie dzwonów.

167-168 (Konkordat zawarty pomiędzy Stolicą Apostolską a Rzplitą Polską); Łukomski, Konkordat zawarty dnia 10 lutego 1925 roku, s. 128; Ruszczyk, Drewniane kościoły w Polsce 1918-1939, s. 104-105.

${ }^{15}$ S. Banach, Archidiecezja Warszawska w latach 1939-1945. Zniszczenia obiektów sakralnych, Dalków 2001, s. 132-135. 
Tabela 2. Dzwony skonfiskowane w diecezji lubelskiej podczas I wojny światowej/ Table 2. Bells confiscated in the Diocese of Lublin during World War I

\begin{tabular}{|c|c|c|}
\hline $\begin{array}{l}\text { Kościól/ } \\
\text { church }\end{array}$ & $\begin{array}{c}\text { Dekanat w } 1919 \text { r./ } \\
\text { deanery in } 1919\end{array}$ & $\begin{array}{l}\text { Liczba utraconych dzwonów/ } \\
\text { the number of lost bells }\end{array}$ \\
\hline Potok Górny & biłgorajski & 1 dzwon \\
\hline Krzeszów & biłgorajski & 1 dzwon \\
\hline $\begin{array}{l}\text { Lublin kościół św. Stanisława } \\
\text { BM }\end{array}$ & lubelski & 1 dzwon \\
\hline Lublin św. Pawła & lubelski & $1 \mathrm{dzwon}$ \\
\hline Józefów nad Wisłą & opolski & 1 dzwon \\
\hline Susiec & tomaszowski & 1 dzwon \\
\hline Czernięcin & turobiński & $1 \mathrm{dzwon}$ \\
\hline Kiełczewice & bełżycki & 2 dzwony \\
\hline Wojciechów & bełżycki & 2 dzwony \\
\hline Niedrzwica & bełżycki & 2 dzwony \\
\hline Puszcza Solska & biłgorajski & 2 dzwony \\
\hline Dorohusk & chełmski & 2 dzwony \\
\hline Pawłów & chełmski & 2 dzwony \\
\hline Horodło & hrubieszowski & 2 dzwony \\
\hline Boża Wola & janowski & 2 dzwony \\
\hline Wilkołaz & kraśnicki & 2 dzwony \\
\hline Bochotnica & kurowski & 2 dzwony \\
\hline Czerniejów & lubelski & 2 dzwony \\
\hline Karczmiska & opolski & 2 dzwony \\
\hline Prawno & opolski & 2 dzwony \\
\hline Kluczkowice & opolski & 2 dzwony \\
\hline Zwierzyniec & szczebrzeszyński & 2 dzwony \\
\hline Józefów Biłgorajski & tarnogrodzki & 2 dzwony \\
\hline Łukowa & tarnogrodzki & 2 dzwony \\
\hline Tarnogród & tarnogrodzki & 2 dzwony \\
\hline Chłaniów & turobiński & 2 dzwony \\
\hline Płonka & turobiński & 2 dzwony \\
\hline Nielisz & szczebrzeszyński & 2 dzwony \\
\hline Niemce & łęczyński & 2 dzwony + sygnaturka \\
\hline Goraj & szczebrzeszyński & 2 dzwony + sygnaturka \\
\hline Rybitwy & opolski & 2 dzwony spalone \\
\hline Krężnica Jara & bełżycki & 3 dzwony \\
\hline Matczyn & bełżycki & 3 dzwony \\
\hline Biskupice & biskupicki & 3 dzwony \\
\hline Piaski Wielkie & biskupicki & 3 dzwony \\
\hline Świerże & chełmski & 3 dzwony \\
\hline Czułczyce & chełmski & 3 dzwony \\
\hline Siedliszcze & chełmski & 3 dzwony \\
\hline Uchanie & hrubieszowski & 3 dzwony \\
\hline
\end{tabular}




\begin{tabular}{|c|c|c|}
\hline Kryłów & hrubieszowski & 3 dzwony \\
\hline Hrubieszów & hrubieszowski & 3 dzwony \\
\hline Trzeszczany & hrubieszowski & 3 dzwony \\
\hline Gorzków & krasnostawski & 3 dzwony \\
\hline Tarnogóra & krasnostawski & 3 dzwony \\
\hline Częstoborowice & krasnostawski & 3 dzwony \\
\hline Zakrzówek & kraśnicki & 3 dzwony \\
\hline Markuszów & kurowski & 3 dzwony \\
\hline Wąwolnica & kurowski & 3 dzwony \\
\hline Garbów & kurowski & 3 dzwony \\
\hline Firlej & lubartowski & 3 dzwony \\
\hline Michów & lubartowski & 3 dzwony \\
\hline $\begin{array}{l}\text { Lublin Kalinowszczyzna } \\
\text { św. Agnieszki }\end{array}$ & lubelski & 3 dzwony \\
\hline Abramowice & lubelski & 3 dzwony \\
\hline Łuszczów & łęczyński & 3 dzwony \\
\hline Puchaczów & łęczyński & 3 dzwony \\
\hline Łęczna & łęczyński & 3 dzwony \\
\hline Wilków & opolski & 3 dzwony \\
\hline Końskowola & puławski & 3 dzwony \\
\hline Włostowice & puławski & 3 dzwony \\
\hline Mokrelipie & szczebrzeszyński & 3 dzwony \\
\hline Radzięcin & szczebrzeszyński & 3 dzwony \\
\hline Szczebrzeszyn & szczebrzeszyński & 3 dzwony \\
\hline Frampol & szczebrzeszyński & 3 dzwony \\
\hline Górecko & tarnogrodzki & 3 dzwony \\
\hline Gródek & tomaszowski & 3 dzwony \\
\hline Rachanie & tomaszowski & 3 dzwony \\
\hline Chodywańce & tomaszowski & 3 dzwony \\
\hline Targowisko & turobiński & 3 dzwony \\
\hline Żółkiewka & turobiński & 3 dzwony \\
\hline Łaszczów & tyszowiecki & 3 dzwony \\
\hline Boby & zaklikowski & 3 dzwony \\
\hline Wysokie & turobiński & 3 dzwony \\
\hline Chodel & bełżycki & 3 dzwony + sygnaturka \\
\hline Biłgoraj & biłgorajski & 3 dzwony + sygnaturka \\
\hline Huta Krzeszowska & biłgorajski & 3 dzwony + sygnaturka \\
\hline Surhów & krasnostawski & 3 dzwony + sygnaturka \\
\hline Dys & lubelski & 3 dzwony + sygnaturka \\
\hline Janów Lubelski & janowski & 3 dzwony spalone \\
\hline Bychawka & bełżycki & 4 dzwony \\
\hline Ratoszyn & bełżycki & 4 dzwony \\
\hline Milejów & biskupicki & 4 dzwony \\
\hline Chełm & chełmski & 4 dzwony \\
\hline Olchowiec & chełmski & 4 dzwony \\
\hline
\end{tabular}




\begin{tabular}{|c|c|c|}
\hline Wojsławice & chełmski & 4 dzwony \\
\hline Moniatycze & hrubieszowski & 4 dzwony \\
\hline Batorz & janowski & 4 dzwony \\
\hline Siennica Różana & krasnostawski & 4 dzwony \\
\hline Urzędów & kraśnicki & 4 dzwony \\
\hline Kurów & kurowski & 4 dzwony \\
\hline Czemierniki & lubartowski & 4 dzwony \\
\hline Lublin Katedra & lubelski & 4 dzwony \\
\hline Lublin Czwartek św. Mikołaj & lubelski & 4 dzwony \\
\hline Piotrawin & opolski & 4 dzwony \\
\hline Kazimierz & puławski & 4 dzwony \\
\hline Tereszpol & szczebrzeszyński & 4 dzwony \\
\hline Księżpol & tarnogrodzki & 4 dzwony \\
\hline Rzeplin & tyszowiecki & 4 dzwony \\
\hline Tyszowce & tyszowiecki & 4 dzwony \\
\hline Nabróż & tyszowiecki & 4 dzwony \\
\hline Dub & tyszowiecki & 4 dzwony \\
\hline Zaklików & zaklikowski & 4 dzwony \\
\hline Kosobudy & zamojski & 4 dzwony \\
\hline \begin{tabular}{|l|} 
Skierbieszów \\
\end{tabular} & zamojski & 4 dzwony \\
\hline Lipsko & zamojski & 4 dzwony \\
\hline Stary Zamość & zamojski & 4 dzwony \\
\hline Turobin & turobiński & 4 dzwony +2 sygnaturki \\
\hline Opole & opolski & 4 dzwony i 2 dzwony zegarowe \\
\hline Fajsławice & biskupicki & 5 dzwonów \\
\hline Łopiennik & krasnostawski & 5 dzwonów \\
\hline Krasnystaw & krasnostawski & 5 dzwonów \\
\hline Kamionka & lubartowski & 5 dzwonów \\
\hline \begin{tabular}{|l|} 
Lubartów \\
\end{tabular} & lubartowski & 5 dzwonów \\
\hline Majdan Sopocki & tarnogrodzki & 5 dzwonów \\
\hline Różaniec & tarnogrodzki & 5 dzwonów \\
\hline Luchów Górny & tarnogrodzki & 5 dzwonów \\
\hline Tomaszów Lubelski & tomaszowski & 5 dzwonów \\
\hline Wożuczyn & tyszowiecki & 5 dzwonów \\
\hline Łabunie & zamojski & 5 dzwonów \\
\hline Oszczów & hrubieszowski & 5 dzwonów + sygnaturka \\
\hline Grabowiec & hrubieszowski & 6 dzwonów \\
\hline Krasnobród & zamojski & 6 dzwonów \\
\hline Biszcza & tarnogrodzki & 8 dzwonów \\
\hline Mełgiew & biskupicki & rekwizycja dzwonów \\
\hline Konopnica & lubelski & rekwizycja dzwonów \\
\hline Łańcuchów & łęczyński & rekwizycja dzwonów \\
\hline Puławy & puławski & rekwizycja dzwonów \\
\hline Sitaniec & zamojski & sygnaturka spalona \\
\hline
\end{tabular}

Źródło: Archiwum Archidiecezji Lubelskiej, Akta Kurii Biskupiej w Lublinie, Wykaz strat wojennych 1919 -1922, sygn. Rep 61 XXI 1. 
Najwięcej dzwonów, bo 8 utracił kościół w Biszczy w dekanacie tarnogrodzkim. Po 6 dzwonów utraciły kościoły w: Grabowcu w dekanacie hrubieszowskim, w Krasnobrodzie w dekanacie zamojskim oraz w Opolu Lubelskim w dekanacie opolskim. Po 5 dzwonów zostało skonfiskowanych z 12 kościołów, po 4 dzwony utraciło 28 kościołów, zaś po 3 dzwony zarekwirowano z 47 kościołów. Z 24 kościołów zagrabiono po 2 dzwony, zaś z 7 po 1 dzwonie. W skali dekanatów najwięcej strat w dzwonach poniósł dekanat tarnogrodzki, następnie hrubieszowski, zamojski, krasnostawski, chełmski, tyszowiecki, bełżycki, a w dalszej kolejności: opolski, szczebrzeszyński, lubelski i lubartowski ${ }^{16}$. Dane dla każdego dekanatu przedstawia tabela $\mathrm{nr} 3$.

Tabela 3. Liczba zarekwirowanych podczas I wojny światowej dzwonów w dekanatach diecezji lubelskiej/

Table 3. The number of bells requisitioned during World War I in deaneries of the Diocese of Lublin.

\begin{tabular}{|c|c|c|}
\hline $\begin{array}{c}\text { Dekanat w } 1919 \text { r./ } \\
\text { deanery in } 1919\end{array}$ & $\begin{array}{l}\text { Liczba dzwonów/ } \\
\text { the number of bells }\end{array}$ & $\begin{array}{l}\text { Liczba sygnaturek/ } \\
\text { the number of little bells }\end{array}$ \\
\hline tarnogrodzki & 36 & \\
\hline hrubieszowski & 29 & 1 \\
\hline zamojski & 27 & 1 \\
\hline krasnostawski & 26 & 1 \\
\hline chełmski & 25 & \\
\hline tyszowiecki & 24 & \\
\hline bełżycki & 23 & 1 \\
\hline opolski & 22 & \\
\hline szczebrzeszyński & 22 & 1 \\
\hline lubelski & powyżej 21 & 1 \\
\hline lubartowski & 20 & \\
\hline turobiński & 18 & 2 \\
\hline biskupicki & powyżej 15 & \\
\hline kurowski & 15 & \\
\hline tomaszowski & 15 & \\
\hline łęczyński & powyżej 11 & 1 \\
\hline biłgorajski & 10 & 2 \\
\hline puławski & powyżej 10 & \\
\hline janowski & 9 & \\
\hline kraśnicki & 9 & \\
\hline zaklikowski & 7 & \\
\hline Ogółem & powyżej 394 & 11 \\
\hline
\end{tabular}

Źródło: AAL, Akta Kurii Biskupiej w Lublinie, Wykaz strat wojennych 1919-1922, sygn. Rep 61 XXI 1.

Proces powojennej odbudowy zniszczonych, bądź uszkodzonych obiektów sakralnych i budynków kościelnych dokonywał się co najmniej przez dwa dzie-

${ }^{16}$ AAL, Akta Kurii Biskupiej w Lublinie, Wykaz strat wojennych 1919-1922, sygn. Rep 61 XXI 1. 
sięciolecia. Jak wykazują zestawienia statystyczne skoncentrowano się w nim głównie na remontach oraz na odbudowie świątyń i budynków kościelnych. Dane do których będziemy się poniżej odwoływać, zebrane zostały w grudniu $1928 \mathrm{r}$. na polecenie MWRiOP, z przeznaczeniem na Powszechną Krajową Wystawę w Poznaniu. W aktach figurują one pod tytułem Statystyka robót, wykonanych w zakresie budownictwa kościelnego za czas od 1 I 1919 do 1 I 192917. Podzielone zostały na trzy grupy: pierwsza to liczba nowo wzniesionych budynków z podziałem na świątynie i inne budynki parafialne, druga to liczba budynków odbudowanych i ostatnia to liczba budynków odremontowanych. Dwie ostatnie także podzielono na świątynie i inne budynki parafialne. Interesują nas głównie świątynie, jednakże dla porównania oraz wykazania proporcji pomiędzy budownictwem sakralnym, a kościelnym postanowiliśmy w tym wypadku uwzględnić także i budynki parafialne. W wykazie zaznaczono również udział i wsparcie ze strony państwa dla wszelkiego rodzaju przedsięwzięć remontowo-budowlanych inicjowanych przy parafiach. Jak wynika ze statystyk zaangażowanie rządu w tym zakresie było minimalne i wyniosło 9,6\%. Oznacza to, że na 728 inicjatyw związanych z budową, odbudową oraz remontami kościołów i budynków przykościelnych, udział państwa zaznaczył się tylko w 70 przypadkach. Szczegółowe dane zawarte są w poniższych tabelach $\mathrm{nr} 4,5$ i 6.

Tabela 4. Szczególowa statystyka robót, wykonanych w zakresie budownictwa kościelnego na obszarze diecezji lubelskiej w latach 1919-1928/

Table 4: Detailed statistics of work made in church construction in the Diocese of Lublin in the years 1919-1928

\begin{tabular}{|c|c|c|c|c|c|c|c|c|c|c|c|c|c|}
\hline \multirow{3}{*}{$\begin{array}{l}\text { Dekanat/ } \\
\text { Lata } \\
\text { deanery/ } \\
\text { years }\end{array}$} & \multicolumn{4}{|c|}{$\begin{array}{l}\text { Liczba budynków nowo } \\
\text { wybudowanych/ the num- } \\
\text { ber of new buildings }\end{array}$} & \multicolumn{4}{|c|}{$\begin{array}{l}\text { Liczba budynków odbu- } \\
\text { dowanych/ the number of } \\
\text { rebuilt buildings }\end{array}$} & \multicolumn{4}{|c|}{$\begin{array}{l}\text { Liczba budynków odre- } \\
\text { montowanych/ the num- } \\
\text { ber of renovated buildings }\end{array}$} & \multirow{3}{*}{$\begin{array}{l}\text { Ogó- } \\
\text { lem/ } \\
\text { total }\end{array}$} \\
\hline & \multicolumn{2}{|c|}{$\begin{array}{c}\text { Liczba } \\
\text { świątyń/ the } \\
\text { number of } \\
\text { churches }\end{array}$} & \multicolumn{2}{|c|}{$\begin{array}{c}\text { Liczba } \\
\text { budynków } \\
\text { parafial- } \\
\text { nych/ the } \\
\text { number of } \\
\text { parish } \\
\text { buildings }\end{array}$} & \multicolumn{2}{|c|}{$\begin{array}{c}\text { Liczba } \\
\text { świątyń/ the } \\
\text { number of } \\
\text { churches }\end{array}$} & \multicolumn{2}{|c|}{$\begin{array}{c}\text { Liczba } \\
\text { budynków } \\
\text { parafial- } \\
\text { nych/ the } \\
\text { number of } \\
\text { parish } \\
\text { buildings }\end{array}$} & \multicolumn{2}{|c|}{$\begin{array}{c}\text { Liczba } \\
\text { świątyń/ the } \\
\text { number of } \\
\text { churches }\end{array}$} & \multicolumn{2}{|c|}{$\begin{array}{c}\text { Liczba } \\
\text { budynków } \\
\text { parafial- } \\
\text { nych/ the } \\
\text { number of } \\
\text { parish } \\
\text { buildings }\end{array}$} & \\
\hline & bprz & pprz & bprz & pprz & bprz & pprz & bprz & pprz & bprz & pprz & bprz & pprz & \\
\hline 1919 & 1 & & 1 & & & & & & & & & & 2 \\
\hline 1920 & & & & & & & & & & & & & 0 \\
\hline 1921 & & & & & & & & & & & 1 & & 1 \\
\hline 1922 & & & & & & & & & & & & & 0 \\
\hline 1923 & & & & & & & & & & & 1 & & 1 \\
\hline
\end{tabular}

${ }^{17}$ AAL, Akta Kurii Biskupiej w Lublinie, Dane statystyczne o budownictwie kościelnym zbierane przez MWRiOP na Powszechną Wystawę Krajową w Poznaniu 1928-1929, sygn. Rep 61 VI 8. 
JOANNA KUMOR-MIELNIK

\begin{tabular}{|c|c|c|c|c|c|c|c|c|c|c|}
\hline 1924 & & & & & & 1 & & & & 1 \\
\hline 1925 & & & & & & & 1 & & & 1 \\
\hline 1926 & & & & & & 1 & & 2 & & 3 \\
\hline 1927 & & & & & & & & & & $\mathbf{0}$ \\
\hline 1928 & & 1 & & & & & & 2 & & 3 \\
\hline bełżycki & & & & & & & & & & $\mathbf{0}$ \\
\hline 1919 & & & 1 & & & & & 1 & & 2 \\
\hline 1920 & & & & & & 1 & & & & 1 \\
\hline 1921 & & & & & & & & & & 0 \\
\hline 1922 & & & & & 1 & & & & 3 & 4 \\
\hline 1923 & & & & & & & & 3 & & 3 \\
\hline 1924 & & 1 & & & & 1 & & 2 & & 4 \\
\hline 1925 & & 1 & & & & & & & & 1 \\
\hline 1926 & & & & & & & & 2 & & 2 \\
\hline 1927 & & & & & & 1 & & & & 1 \\
\hline 1928 & & & & & & & & & & $\mathbf{0}$ \\
\hline biłgorajski & & & & & & & & & & $\mathbf{0}$ \\
\hline 1919 & & & & & & & & 1 & & 1 \\
\hline 1920 & & & & & & 1 & & & & 1 \\
\hline 1921 & & & & & & 1 & & & & 1 \\
\hline 1922 & & & & & & 3 & & & & 3 \\
\hline 1923 & & & & & & 1 & & 2 & & 3 \\
\hline 1924 & & & & & & 1 & & 3 & & 4 \\
\hline 1925 & & & & & & 2 & & & & 2 \\
\hline 1926 & 1 & 4 & & & & 3 & & 3 & & 11 \\
\hline 1927 & & 4 & & & & 7 & & 6 & & 17 \\
\hline 1928 & & & & & & 3 & & 1 & & 4 \\
\hline bychawski & & & & & & & & & & $\mathbf{0}$ \\
\hline 1919 & & & & 1 & & 1 & & & & 2 \\
\hline 1920 & & & & & & & & & & $\mathbf{0}$ \\
\hline 1921 & & & & & & & & & & $\mathbf{0}$ \\
\hline 1922 & & & & & & & & & & 0 \\
\hline 1923 & & & & & & & & & & $\mathbf{0}$ \\
\hline 1924 & & & & & & 1 & & & & 1 \\
\hline 1925 & & 2 & & & & & & 1 & & 3 \\
\hline 1926 & & & & & & 1 & & & & 1 \\
\hline 1927 & & & & & & 1 & & & & 1 \\
\hline
\end{tabular}




\begin{tabular}{|c|c|c|c|c|c|c|c|c|c|c|c|c|}
\hline 1928 & & & 4 & & & & & 1 & & & & 5 \\
\hline chełmski & & & & & & & & & & & & $\mathbf{0}$ \\
\hline 1919 & & & & & & 1 & & 1 & & & & 2 \\
\hline 1920 & & & & & & & & 1 & & 2 & & 3 \\
\hline 1921 & & & & 1 & & & 1 & & & & 2 & 4 \\
\hline 1922 & & & & 2 & & & 2 & & & 3 & & 7 \\
\hline 1923 & & & & & & & & & 2 & & 3 & 5 \\
\hline 1924 & 1 & & 2 & 3 & 1 & 2 & & & 1 & & & 10 \\
\hline 1925 & & & & & & 2 & & & & & & 2 \\
\hline 1926 & & & 5 & & & 2 & & & 2 & 2 & & 11 \\
\hline 1927 & & & 2 & & & & & 2 & & & & 4 \\
\hline 1928 & & & 2 & & & 1 & 1 & 2 & & 4 & & 10 \\
\hline $\begin{array}{l}\text { hrubie- } \\
\text { szowski }\end{array}$ & & & & & & & & & & & & $\mathbf{0}$ \\
\hline 1919 & & & & & & & & 1 & & 1 & & 2 \\
\hline 1920 & & & & & & & & 4 & & 4 & & 8 \\
\hline 1921 & & 1 & 1 & 1 & & & & 1 & & 2 & 1 & 7 \\
\hline 1922 & & & 3 & & & & & 1 & & 3 & & 7 \\
\hline 1923 & 1 & 1 & & 2 & & & & 4 & & 6 & 2 & 16 \\
\hline 1924 & 2 & & & & & & & 3 & & 3 & & 8 \\
\hline 1925 & & & 2 & & & & & 1 & & 4 & & 7 \\
\hline 1926 & & & & & & & & 1 & & 3 & & 4 \\
\hline 1927 & & & & & & & & 2 & & 5 & & 7 \\
\hline 1928 & & & & & & & & & & 2 & & 2 \\
\hline $\begin{array}{l}\text { janowski } \\
\text { lubelski }\end{array}$ & & & & & & & & & & & & $\mathbf{0}$ \\
\hline 1919 & & & 4 & & & & & 3 & & & & 7 \\
\hline 1920 & & & & & & & & & & & & $\mathbf{0}$ \\
\hline 1921 & & & & & & & & & & & & $\mathbf{0}$ \\
\hline 1922 & 1 & & & & & & & & & 3 & & 4 \\
\hline 1923 & & & & & & & & & & & & $\mathbf{0}$ \\
\hline 1924 & & & & & & & & & & & & $\mathbf{0}$ \\
\hline 1925 & & & 3 & & & & & & & 1 & & 4 \\
\hline 1926 & & 1 & 4 & & & & & & & 2 & & 7 \\
\hline 1927 & 1 & & 1 & & & & & & & 1 & & 3 \\
\hline 1928 & 2 & & 5 & & & & & 1 & & 2 & & 10 \\
\hline kraśnicki & & & & & & & & & & & & $\mathbf{0}$ \\
\hline 1919 & & & & & & & & 1 & & & & 1 \\
\hline
\end{tabular}


JOANNA KUMOR-MIELNIK

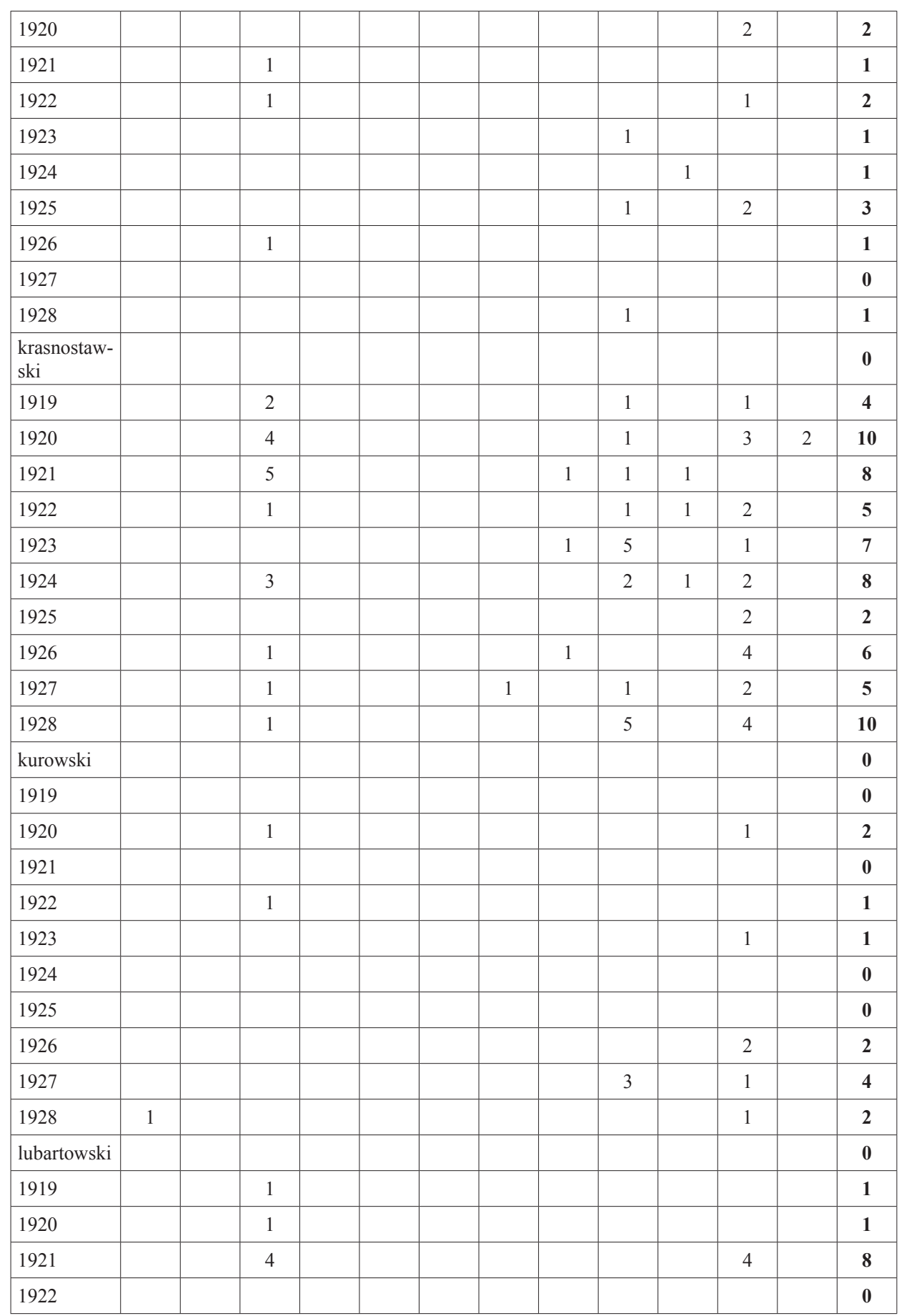




\begin{tabular}{|c|c|c|c|c|c|c|c|c|c|c|c|}
\hline 1923 & & & & & & & & & & & $\mathbf{0}$ \\
\hline 1924 & 2 & 9 & & & & & & & & & 11 \\
\hline 1925 & 1 & 9 & & & & & 1 & & & & 11 \\
\hline 1926 & & & & & & & & & & & $\mathbf{0}$ \\
\hline 1927 & 1 & 5 & & & & & & & & & 6 \\
\hline 1928 & & 3 & & & & & 1 & & 3 & & 7 \\
\hline łęczyński & & & & & & & & & & & $\mathbf{0}$ \\
\hline 1919 & & 5 & & & 5 & & & & 1 & & 11 \\
\hline 1920 & & & & & & & & & & & 0 \\
\hline 1921 & & & & & & & & & & & 0 \\
\hline 1922 & & & & & & & & & 2 & & 2 \\
\hline 1923 & & & & & & & 1 & & & & 1 \\
\hline 1924 & & & 1 & & & & 1 & & & & 2 \\
\hline 1925 & & 1 & & & & & 1 & & 1 & & 3 \\
\hline 1926 & & & & & & & 2 & & 1 & & 3 \\
\hline 1927 & & 2 & & & & & 1 & & 2 & & 5 \\
\hline 1928 & & 2 & & & & & & & & & 2 \\
\hline opolski & & & & & & & & & & & 0 \\
\hline 1919 & & & & & & & & & & & 0 \\
\hline 1920 & & & & & & 3 & & 2 & & 3 & 8 \\
\hline 1921 & & & & & & & & & 2 & & 2 \\
\hline 1922 & & & & & & & & & & & $\mathbf{0}$ \\
\hline 1923 & & & & & & & & & & & 0 \\
\hline 1924 & & 3 & 2 & & & & & & 2 & & 7 \\
\hline 1925 & 1 & & & & 2 & & & & & & 3 \\
\hline 1926 & & & 1 & & & & 1 & & & & 2 \\
\hline 1927 & & & & & & & & & 2 & & 2 \\
\hline 1928 & & & & & & & & & & & $\mathbf{0}$ \\
\hline piasecki & & & & & & & & & & & $\mathbf{0}$ \\
\hline 1919 & & & & & & & & & & & $\mathbf{0}$ \\
\hline 1920 & & & & 1 & & & & & & & 1 \\
\hline 1921 & 1 & & & & 2 & & 1 & & & & 4 \\
\hline 1922 & & 4 & & & & & & & & & 4 \\
\hline 1923 & & 2 & & & & & 1 & & & & 3 \\
\hline 1924 & & & & & & & & & & & $\mathbf{0}$ \\
\hline 1925 & & 2 & & & 1 & & & & 1 & & 4 \\
\hline 1926 & & 1 & & & & & 1 & & & & 2 \\
\hline
\end{tabular}




\begin{tabular}{|c|c|c|c|c|c|c|c|c|c|}
\hline 1927 & & & & & 2 & & & & 2 \\
\hline 1928 & 1 & & & & 3 & & 3 & & 7 \\
\hline puławski & & & & & & & & & 0 \\
\hline 1919 & & & & & & & & & $\mathbf{0}$ \\
\hline 1920 & & & & & & & & & $\mathbf{0}$ \\
\hline 1921 & & & & & & & & & $\mathbf{0}$ \\
\hline 1922 & & & & & 1 & 1 & & & 2 \\
\hline 1923 & & & 1 & & & & & & 1 \\
\hline 1924 & & & & 2 & 1 & & & & 3 \\
\hline 1925 & 1 & & & & 1 & & & & 2 \\
\hline 1926 & & & & 1 & 3 & & & & 4 \\
\hline 1927 & & & & 1 & 2 & & 3 & & 6 \\
\hline 1928 & 1 & & & & 1 & & 2 & & 4 \\
\hline $\begin{array}{l}\text { szczebrze- } \\
\text { szyński }\end{array}$ & & & & & & & & & $\mathbf{0}$ \\
\hline 1919 & & & & & & & & & $\mathbf{0}$ \\
\hline 1920 & & & & & & & 1 & & 1 \\
\hline 1921 & 1 & & & & 1 & & 1 & & 3 \\
\hline 1922 & & & & & & & & & $\mathbf{0}$ \\
\hline 1923 & 1 & & & & 1 & & 1 & & 3 \\
\hline 1924 & & & & & 1 & & 1 & & 2 \\
\hline 1925 & & & & & 2 & & 4 & & 6 \\
\hline 1926 & 1 & & 1 & & 1 & & 3 & & 6 \\
\hline 1927 & 1 & & & & 2 & 1 & 2 & & 6 \\
\hline 1928 & 5 & & & & & & 1 & & 6 \\
\hline $\begin{array}{l}\text { tarnogrodz- } \\
\text { ki }\end{array}$ & & & & & & & & & 0 \\
\hline 1919 & 1 & & & & & & & & 1 \\
\hline 1920 & 4 & & & & & 1 & 1 & 1 & 7 \\
\hline 1921 & 3 & & & & 1 & & & & 4 \\
\hline 1922 & 2 & & & & & & 1 & & 3 \\
\hline 1923 & 1 & & & & & 1 & & & 2 \\
\hline 1924 & 3 & & & 1 & 1 & & & & 5 \\
\hline 1925 & 2 & & & 1 & & & 2 & & 5 \\
\hline 1926 & 1 & 1 & & & 2 & & & & 4 \\
\hline 1927 & 2 & 1 & & & & & 2 & & 5 \\
\hline 1928 & 1 & 3 & & & 1 & 1 & 2 & 1 & 9 \\
\hline $\begin{array}{l}\text { tomaszow- } \\
\text { ski }\end{array}$ & & & & & & & & & $\mathbf{0}$ \\
\hline
\end{tabular}




\begin{tabular}{|c|c|c|c|c|c|c|c|}
\hline 1919 & & & & & & & $\mathbf{0}$ \\
\hline 1920 & & 1 & & & & & 1 \\
\hline 1921 & & & & & & & 0 \\
\hline 1922 & & & & & 1 & 1 & 2 \\
\hline 1923 & & & & & & & $\mathbf{0}$ \\
\hline 1924 & & 1 & & & & & 1 \\
\hline 1925 & & 1 & & & & & 1 \\
\hline 1926 & & 2 & & & & & 2 \\
\hline 1927 & 1 & 4 & & & & 1 & 6 \\
\hline 1928 & & 1 & & 1 & & & 2 \\
\hline turobiński & & & & & & & 0 \\
\hline 1919 & & & & & & 1 & 1 \\
\hline 1920 & & & & & & & 0 \\
\hline 1921 & & & & & & 4 & 4 \\
\hline 1922 & & & 1 & & & & 1 \\
\hline 1923 & & & & & & & 0 \\
\hline 1924 & & 1 & & & & 1 & 2 \\
\hline 1925 & & 1 & & & 1 & & 2 \\
\hline 1926 & & & & & 1 & & 1 \\
\hline 1927 & & & & & 2 & 3 & 5 \\
\hline 1928 & & & 1 & & 1 & & 2 \\
\hline tyszowiecki & & & & & & & 0 \\
\hline 1919 & & & & & & & $\mathbf{0}$ \\
\hline 1920 & & & & & & & $\mathbf{0}$ \\
\hline 1921 & & & & & 1 & & 1 \\
\hline 1922 & 1 & 1 & & & & & 2 \\
\hline 1923 & & 5 & & & & 9 & 14 \\
\hline 1924 & & 1 & & & 1 & 4 & 6 \\
\hline 1925 & & & & & 1 & 11 & 12 \\
\hline 1926 & & 1 & & & & 5 & 6 \\
\hline 1927 & & 5 & & & 1 & 1 & 7 \\
\hline 1928 & & 1 & & & 1 & 9 & 11 \\
\hline $\begin{array}{l}\text { zaklikowski } \\
\text { (nie wyko- } \\
\text { nano żad- } \\
\text { nych robót) }\end{array}$ & & & & & & & 0 \\
\hline zamojski & & & & & & & $\mathbf{0}$ \\
\hline 1919 & & 1 & & & 3 & 2 & 6 \\
\hline
\end{tabular}




\begin{tabular}{|l|c|c|c|c|c|c|c|c|c|c|c|c|c|}
\hline 1920 & 1 & & 2 & & 2 & & & & 2 & & & 7 \\
\hline 1921 & & & 4 & & 1 & & & & & 1 & 1 & & 7 \\
\hline 1922 & & & 3 & & & & 1 & & 3 & & 1 & $\mathbf{8}$ \\
\hline 1923 & & & 3 & & & & 2 & & 1 & & 1 & & 7 \\
\hline 1924 & & & 4 & & & & 1 & & & & 1 & & $\mathbf{6}$ \\
\hline 1925 & & & 6 & & & & 1 & & 1 & & 2 & & $\mathbf{1 0}$ \\
\hline 1926 & & & 4 & & & & 1 & & & & 3 & & $\mathbf{8}$ \\
\hline 1927 & & & 3 & & & & & & 1 & & 2 & & $\mathbf{6}$ \\
\hline 1928 & & & 1 & & & & & & 3 & & 1 & $\mathbf{5}$ \\
\hline Ogółem & $\mathbf{2 0}$ & $\mathbf{3}$ & $\mathbf{2 1 8}$ & $\mathbf{1 8}$ & $\mathbf{8}$ & $\mathbf{2}$ & $\mathbf{3 3}$ & $\mathbf{1 1}$ & $\mathbf{1 4 8}$ & $\mathbf{1 8}$ & $\mathbf{2 3 1}$ & $\mathbf{1 8}$ & $\mathbf{7 2 8}$ \\
\hline
\end{tabular}

bprz - bez pomocy rządu/ without the assistance of government

pprz - przy pomocy rządu/ with the assistance of government

Źródło: AAL, Akta Kurii Biskupiej w Lublinie, Dane statystyczne o budownictwie kościelnym zbierane przez MWRiOP na Powszechna Wystawę Krajowa w Poznaniu 1928-1929, sygn. Rep 61 VI 8.

Tabela 5. Zbiorcza statystyka robót, wykonanych w zakresie budownictwa kościelnego w dekanatach diecezji lubelskiej w latach 1919-1928/

Table 5. Summary statistics of work made in church construction in the deaneries of the Diocese of Lublin in the years 1919-1928

\begin{tabular}{|c|c|c|c|c|c|c|c|c|c|c|c|c|c|}
\hline \multirow{3}{*}{$\begin{array}{l}\text { Dekanaty/ } \\
\text { deanery }\end{array}$} & \multicolumn{4}{|c|}{$\begin{array}{l}\text { Liczba budynków nowo } \\
\text { wybudowanych/the num- } \\
\text { ber of new buildings }\end{array}$} & \multicolumn{4}{|c|}{$\begin{array}{l}\text { Liczba budynków odbu- } \\
\text { dowanych/ the number of } \\
\text { rebuilt buildings }\end{array}$} & \multicolumn{4}{|c|}{$\begin{array}{l}\text { Liczba budynków odre- } \\
\text { montowanych/ the num- } \\
\text { ber of renovated buildings }\end{array}$} & \multirow{3}{*}{$\begin{array}{l}\text { Ogó- } \\
\text { lem/ } \\
\text { total }\end{array}$} \\
\hline & \multicolumn{2}{|c|}{$\begin{array}{c}\text { Liczba } \\
\text { świątyń/ the } \\
\text { number of } \\
\text { churches }\end{array}$} & \multicolumn{2}{|c|}{$\begin{array}{c}\text { Liczba } \\
\text { budynków } \\
\text { parafial- } \\
\text { nych/ the } \\
\text { number of } \\
\text { parish } \\
\text { buildings }\end{array}$} & \multicolumn{2}{|c|}{$\begin{array}{c}\text { Liczba } \\
\text { świątyń/ the } \\
\text { number of } \\
\text { churches }\end{array}$} & \multicolumn{2}{|c|}{$\begin{array}{c}\text { Liczba } \\
\text { budynków } \\
\text { parafial- } \\
\text { nych/ the } \\
\text { number of } \\
\text { parish } \\
\text { buildings }\end{array}$} & \multicolumn{2}{|c|}{$\begin{array}{c}\text { Liczba } \\
\text { świątyń/ the } \\
\text { number of } \\
\text { churches }\end{array}$} & \multicolumn{2}{|c|}{$\begin{array}{c}\text { Liczba } \\
\text { budynków } \\
\text { parafial- } \\
\text { nych/ the } \\
\text { number of } \\
\text { parish } \\
\text { buildings }\end{array}$} & \\
\hline & bprz & pprz & bprz & pprz & bprz & pprz & bprz & pprz & bprz & pprz & bprz & pprz & \\
\hline zamojski & 1 & 0 & 31 & 0 & 3 & 0 & 6 & 0 & 14 & 1 & 14 & 0 & 70 \\
\hline $\begin{array}{c}\text { hrubieszow- } \\
\text { ski }\end{array}$ & 3 & 2 & 6 & 3 & 0 & 0 & 0 & 0 & 18 & 0 & 33 & 3 & 68 \\
\hline $\begin{array}{c}\text { krasnostaw- } \\
\text { ski }\end{array}$ & 0 & 0 & 18 & 0 & 0 & 0 & 1 & 3 & 17 & 3 & 21 & 2 & 65 \\
\hline tyszowiecki & 1 & 0 & 14 & 0 & 0 & 0 & 0 & 0 & 5 & 0 & 39 & 0 & 59 \\
\hline chełmski & 1 & 0 & 11 & 6 & 0 & 1 & 8 & 4 & 6 & 5 & 11 & 5 & 58 \\
\hline biłgorajski & 1 & 0 & 8 & 0 & 0 & 0 & 0 & 0 & 22 & 0 & 16 & 0 & 47 \\
\hline lubartowski & 4 & 0 & 32 & 0 & 0 & 0 & 0 & 0 & 2 & 0 & 7 & 0 & 45 \\
\hline $\begin{array}{c}\text { tarnogrodz- } \\
\mathrm{ki} \\
\end{array}$ & 0 & 0 & 20 & 5 & 0 & 0 & 2 & 0 & 5 & 3 & 8 & 2 & 45 \\
\hline $\begin{array}{c}\text { janowski } \\
\text { lubelski }\end{array}$ & 4 & 1 & 17 & 0 & 0 & 0 & 0 & 0 & 4 & 0 & 9 & 0 & 35 \\
\hline
\end{tabular}




\begin{tabular}{|c|c|c|c|c|c|c|c|c|c|c|c|c|c|}
\hline $\begin{array}{c}\text { szczebrze- } \\
\text { szyński }\end{array}$ & 0 & 0 & 9 & 0 & 1 & 0 & 0 & 0 & 8 & 1 & 14 & 0 & $\mathbf{3 3}$ \\
\hline łęczyński & 0 & 0 & 10 & 1 & 0 & 0 & 5 & 0 & 6 & 0 & 7 & 0 & $\mathbf{2 9}$ \\
\hline piasecki & 1 & 0 & 10 & 0 & 1 & 0 & 3 & 0 & 8 & 0 & 4 & 0 & $\mathbf{2 7}$ \\
\hline opolski & 1 & 0 & 3 & 3 & 0 & 0 & 2 & 3 & 1 & 2 & 6 & 3 & $\mathbf{2 4}$ \\
\hline puławski & 0 & 0 & 2 & 0 & 1 & 0 & 4 & 0 & 9 & 1 & 5 & 0 & $\mathbf{2 2}$ \\
\hline bełżycki & 0 & 0 & 2 & 0 & 0 & 1 & 0 & 1 & 3 & 0 & 8 & 3 & $\mathbf{1 8}$ \\
\hline turobiński & 0 & 0 & 2 & 0 & 2 & 0 & 0 & 0 & 5 & 0 & 9 & 0 & $\mathbf{1 8}$ \\
\hline $\begin{array}{c}\text { tomaszow- } \\
\text { ski }\end{array}$ & 1 & 0 & 10 & 0 & 0 & 0 & 1 & 0 & 1 & 0 & 2 & 0 & $\mathbf{1 5}$ \\
\hline bychawski & 0 & 0 & 6 & 0 & 0 & 0 & 1 & 0 & 5 & 0 & 1 & 0 & $\mathbf{1 3}$ \\
\hline kraśnicki & 0 & 0 & 3 & 0 & 0 & 0 & 0 & 0 & 4 & 1 & 5 & 0 & $\mathbf{1 3}$ \\
\hline lubelski & 1 & 0 & 2 & 0 & 0 & 0 & 0 & 0 & 2 & 1 & 6 & 0 & $\mathbf{1 2}$ \\
\hline kurowski & 1 & 0 & 2 & 0 & 0 & 0 & 0 & 0 & 3 & 0 & 6 & 0 & $\mathbf{1 2}$ \\
\hline zaklikowski & 0 & 0 & 0 & 0 & 0 & 0 & 0 & 0 & 0 & 0 & 0 & 0 & $\mathbf{0}$ \\
\hline Ogółem & $\mathbf{2 0}$ & $\mathbf{3}$ & $\mathbf{2 1 8}$ & $\mathbf{1 8}$ & $\mathbf{8}$ & $\mathbf{2}$ & $\mathbf{3 3}$ & $\mathbf{1 1}$ & $\mathbf{1 4 8}$ & $\mathbf{1 8}$ & $\mathbf{2 3 1}$ & $\mathbf{1 8}$ & $\mathbf{7 2 8}$ \\
\hline
\end{tabular}

bprz - bez pomocy rządu/ without the assistance of governmen

pprz - przy pomocy rządu/ with the assistance of government

Źródło: AAL, Akta Kurii Biskupiej w Lublinie, Dane statystyczne o budownictwie kościelnym zbierane przez MWRiOP na Powszechna Wystawe Krajowa w Poznaniu 1928-1929, sygn. Rep 61 VI 8.

Na podstawie statystyk zawartych w tabeli 4 i 5 możemy powiedzieć, iż na 728 parafialnych inicjatyw budowlanych, zrealizowanych w latach 1919-1928 tylko 23 związane były z budową kościołów. Na 23 nowo wzniesione kościoły, zaledwie 3 uzyskały pomoc rządu. Dziesięciokrotnie więcej, bo aż 236 powstało wówczas innych budynków parafialnych, z czego tylko 18 wybudowanych zostało przy współudziale państwa. Liczba odbudowanych kościołów wyniosła w tym okresie 10, zaś odremontowanych kościołów odnotowano 166 . W pierwszym wypadku państwo udzieliło swojego wsparcia 2 świątyniom, natomiast w drugim 11. Znacznie wyższa była liczba odbudowanych oraz wyremontowanych innych budynków kościelnych, która wyniosła odpowiednio 44 i 349.

Najwięcej przedsięwzięć, związanych z budową, odbudową oraz remontem kościołów oraz innych budynków parafialnych podjęto $\mathrm{w}$ dekanacie zamojskim, następnie hrubieszowskim, krasnostawskim, tyszowieckim, chełmskim. Z kolei najmniej wykonano ich w dekanatach: kurowskim, lubelskim, kraśnickim, bychawskim, tomaszowskim. Żadnych prac nie podjęto w dekanacie zaklikowskim. Natężenie prac wykonywanych w poszczególnych latach nie było jednakowe i z każdym kolejnym rokiem wykazywało tendencje wzrostowe, co przedstawia nam wykres 1 oraz tabela 6 . Najwięcej kościołów - 5 wzniesiono w roku 1924, zaś po 3 świątynie wybudowano w roku 1927 i 1928. W tych dwóch ostatnich latach odnotowano też największą liczbę świątyń odremontowanych.

Jednakże skala inwestycji sakralnych, związanych ściśle z kościołami, w stosunku do pozostałych inicjatyw odnoszących się do budynków parafialnych, była bardzo niska. Udział nowo wzniesionych świątyń, w ogólnej liczbie kościelnych przedsięwzięć remontowo-budowlanych w diecezji lubelskiej wyniósł zaledwie $3,2 \%$. Z kolei udział kościołów odbudowanych nieznacznie przekroczył 1\%, zaś 
udział świątyń wyremontowanych wyniósł blisko 23\%. Ogółem udział wszystkich rodzajów prac wykonywanych przy świątyniach osiągnął wynik $27,3 \%$.

Tabela 6. Statystyka robót, wykonanych w zakresie budownictwa kościelnego na obszarze diecezji lubelskiej od roku 1919 do 1928/

Table 6: Statistics of work made in church construction in the Diocese of Lublin from 1919 until 1928.

\begin{tabular}{|c|c|c|c|c|c|c|c|c|c|c|c|c|c|}
\hline \multirow{3}{*}{$\begin{array}{l}\text { Lata/ } \\
\text { years }\end{array}$} & \multicolumn{4}{|c|}{$\begin{array}{l}\text { Liczba budynków nowo } \\
\text { wybudowanych/ the num- } \\
\text { ber of new buildings }\end{array}$} & \multicolumn{4}{|c|}{$\begin{array}{c}\text { Liczba budynków odbudo- } \\
\text { wanych/ the number of } \\
\text { rebuilt buildings }\end{array}$} & \multicolumn{4}{|c|}{$\begin{array}{c}\text { Liczba budynków odremon- } \\
\text { towanych/ the number of } \\
\text { renovated buildings }\end{array}$} & \multirow{3}{*}{$\begin{array}{l}\text { Ogó- } \\
\text { lem/ } \\
\text { total }\end{array}$} \\
\hline & \multicolumn{2}{|c|}{$\begin{array}{c}\text { Liczba świą- } \\
\text { tyń/ the } \\
\text { number of } \\
\text { churches }\end{array}$} & \multicolumn{2}{|c|}{$\begin{array}{c}\text { Liczba } \\
\text { budynków } \\
\text { parafialnych/ } \\
\text { the number } \\
\text { of parish } \\
\text { buildings }\end{array}$} & \multicolumn{2}{|c|}{$\begin{array}{c}\text { Liczba } \\
\text { świątyń/ the } \\
\text { number of } \\
\text { churches }\end{array}$} & \multicolumn{2}{|c|}{$\begin{array}{c}\text { Liczba } \\
\text { budynków } \\
\text { parafialnych/ } \\
\text { the number } \\
\text { of parish } \\
\text { buildings }\end{array}$} & \multicolumn{2}{|c|}{$\begin{array}{l}\text { Liczba świą- } \\
\text { tyń/ the } \\
\text { number of } \\
\text { churches }\end{array}$} & \multicolumn{2}{|c|}{$\begin{array}{c}\text { Liczba } \\
\text { budynków } \\
\text { parafialnych/ } \\
\text { the number } \\
\text { of parish } \\
\text { buildings }\end{array}$} & \\
\hline & bprz & pprz & bprz & pprz & bprz & pprz & bprz & pprz & bprz & pprz & bprz & pprz & \\
\hline 1919 & 1 & 0 & 15 & 0 & 0 & 1 & 7 & 0 & 11 & 0 & 8 & 0 & 43 \\
\hline 1920 & 1 & 0 & 13 & 0 & 3 & 0 & 0 & 3 & 10 & 3 & 14 & 6 & 53 \\
\hline 1921 & 1 & 1 & 19 & 2 & 1 & 0 & 2 & 2 & 7 & 2 & 15 & 3 & 55 \\
\hline 1922 & 2 & 0 & 16 & 2 & 1 & 0 & 1 & 3 & 10 & 2 & 17 & 3 & 57 \\
\hline 1923 & 1 & 1 & 12 & 2 & 1 & 0 & 2 & 1 & 15 & 3 & 25 & 5 & 68 \\
\hline 1924 & 5 & 0 & 28 & 6 & 0 & 1 & 6 & 0 & 14 & 3 & 19 & 0 & 82 \\
\hline 1925 & 2 & 0 & 31 & 0 & 0 & 0 & 7 & 0 & 12 & 1 & 31 & 0 & 84 \\
\hline 1926 & 1 & 1 & 25 & 2 & 1 & 0 & 4 & 1 & 17 & 2 & 32 & 0 & 86 \\
\hline 1927 & 3 & 0 & 30 & 1 & 0 & 0 & 2 & 0 & 28 & 1 & 33 & 0 & 98 \\
\hline 1928 & 3 & 0 & 29 & 3 & 1 & 0 & 2 & 1 & 24 & 1 & 37 & 1 & 102 \\
\hline $\begin{array}{l}\text { Ogó- } \\
\text { łem }\end{array}$ & 20 & 3 & 218 & 18 & 8 & 2 & 33 & 11 & 148 & 18 & 231 & 18 & 728 \\
\hline
\end{tabular}

bprz - bez pomocy rządu/ without the assistance of government pprz - przy pomocy rządu/ with the assistance of government

Źródło: AAL, Akta Kurii Biskupiej w Lublinie, Dane statystyczne o budownictwie kościelnym zbierane przez MWRiOP na Powszechna Wystawe Krajowa w Poznaniu 1928-1929, sygn. Rep 61 VI 8. 


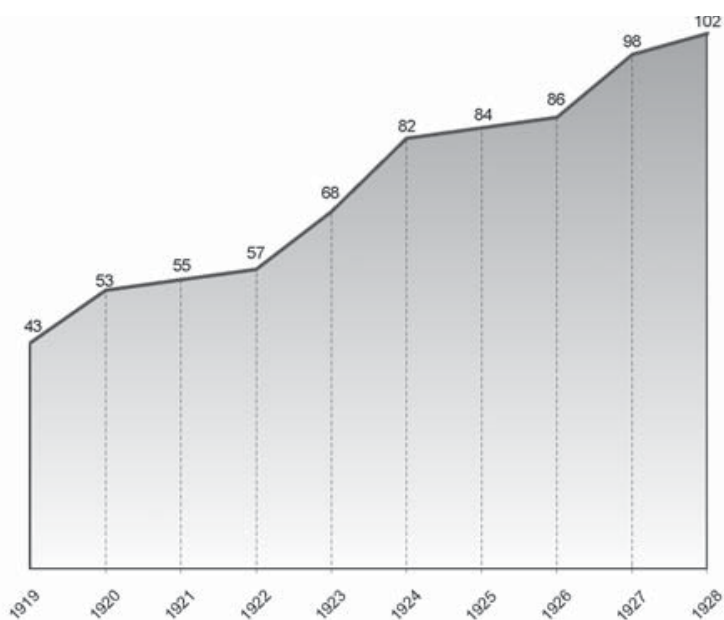

Wykres 1. Liczba kościelnych inwestycji remontowo-budowlanych podjętych na obszarze diecezji lubelskiej w latach 1919-1928

Graph 1: The number of church investments in renovation and construction undertaken in the Diocese of Lublin in the years 1919-1928

Przytoczona już liczba 16 kościołów parafialnych wzniesionych w latach 1918-1930 uznana została w naszej ocenie za niewysoką, argumentowaną ukierunkowaniem prac w pierwszej kolejności na odbudowę ze zniszczeń powojennych, nie zaś na wznoszenie nowych świątyń. Ponadto ograniczone do minimum dotacje ze strony państwa na budowę nowych świątyń, przy jednoczesnym zubożeniu społeczeństwa, nastręczały dodatkowych trudności związanych z brakiem funduszy na pokrycie kosztów, jakie niosły ze sobą przedsięwzięcia budowlane.

W latach 1931-1939, mając na uwadze 20 nowo wybudowanych kościołów: 9 drewnianych, 10 murowanych oraz 1 murowano-drewniany, priorytetowym ponownie okazał się być ruch budowy kościołów parafialnych. Wzniesionych w tym okresie 10 murowanych kościołów parafialnych znajdowało się w następujących parafiach: Zagłoba, Polichna, Starościn, Stara Wieś, Godziszów, Suchowola Zamojska, Babin, Brzeźnica Książęca, oraz w 2 parafiach w Lublinie: pw. św. Michała Archanioła oraz pw. Najświętszego Zbawiciela. Świątynie drewniane pobudowano w parafii Gilów, Chrzanów, Tworyczów, Jastków, Aleksandrów, Olbięcin, Kanie, Momoty oraz w Lublinie w parafii pw. Najświętszego Serca Jezusowego. Także w Lublinie powstał kościół murowano-drewniany pw. św. Teresy od Dzieciątka Jezus. Podobnie jak w poprzednim dziesięcioleciu, na uwagę zasługuje dość wysoka liczba wybudowanych w latach 1931-1939 kościołów drewnianych w stosunku do ilości kościołów murowanych. Oprócz 20 nowych świątyń diecezji lubelskiej, których budowę sfinalizowano w latach 1931-1939, jeszcze przed wybuchem II wojny światowej przystąpiono do budowy 6 kolejnych kościołów parafialnych, z czego tylko jeden był drewniany - w parafii Tuczępy, a pozostałych 5 było murowanych: Annopol, Branew, Matczyn, Tomaszów Lubelski pw. Najświętszego Serca Pana Jezusa, oraz Zamość pw. Krzyża Świętego. Prace budowlane tychże kościołów zakończono dopiero po wojnie. 
Zaobserwowany w diecezji lubelskiej pod koniec lat 20. XX w. postęp w budownictwie kościołów parafialnych, nie zdążył się w pełni rozwinąć, ze względu na wybuch II wojny światowej. Ponadto wzrost liczby kościołów drewnianych, odnotowany w latach 1918-1930 oraz w następnym dziesięcioleciu, ma swoje uzasadnienie w stosunkowo łatwej dostępności i niskiej cenie drewnianego budulca $\mathrm{w}$ tym okresie. Budownictwo drewnianych świątyń, zaznaczy się również w latach 1950-1960, a swoje przyczyny będzie miało głównie w braku i niedostępności, innego niż drewno materiału budowlanego (podlegającemu od $1953 \mathrm{r}$. centralnemu rozdzielnictwu).

słowa kluczowe: diecezja lubelska, zniszczenia wojenne, I wojna światowa, kościół, dzwony, budownictwo sakralne

\title{
AN OUTLINE OF CONSTRUCTION ISSUES AND WAR LOSSES IN PARISH CHURCHES OF THE DIOCESE OF LUBLIN AFTER | THE FIRST WORLD WAR
}

\begin{abstract}
Summary
The content of this article is an introduction to a wider spectrum of the issues related to losses of life and material things the Diocese of Lublin suffered after the First World War.

The article focuses on two major issues related firstly to the reconstruction of destroyed parish churches in the Diocese of Lublin in the postwar period and using for this purpose state subsidies and funds from the contributions of the parishioners; and secondly, related to the dynamics and intensity of the construction of new parish churches at that time. The rebuilding of churches and buildings connected with them was a priority in the field of renovation and construction projects after World War I. The matter of less importance was to initiate the construction of new churches, erected mainly at the expense of parishioners, rarely with the use of state subsidies. In the 1930s the movement of building parish churches intensified. It was, however, a short-lived process, interrupted by the outbreak of another war. The dynamic growth in the number of new churches, observed in a relatively short period of time was caused, among other things, by the use of cheaper and more readily available wood, which resulted in the increase in wooden churches in the interwar period. The concise characterization of building regulations in the context of the construction of parish churches in the postwar period, the same as in the case of other issues, requires further research and in-depth analysis.
\end{abstract}

Keywords: the Diocese of Lublin, war damage, World War I, church, bells, religious buildings 